\title{
Evisceración testicular
}

\author{
Lorente Pérez FJ.
}

Servicio de Urología. Clinica San Miguel. Pamplona.

Actas Urol Esp. 2008;32(5):572

$\mathrm{P}$ aciente de 52 años de edad que es atendido de urgencia tras haber sufrido un accidente laboral al resultar golpeado, según refiere, con una máquina en la región genital, aunque no reconoce exactamente el mecanismo de producción del traumatismo.

Presenta una evisceración de teste derecho, con pérdida de aproximadamente el $50 \%$ de pared escrotal derecha secundaria a sección limpia de la misma, sin afectación testicular ni peneana.

Tras comprobar integridad testicular, se realiza sutura primaria de hemiescroto derecho y reposición testicular, con buen resultado estético.

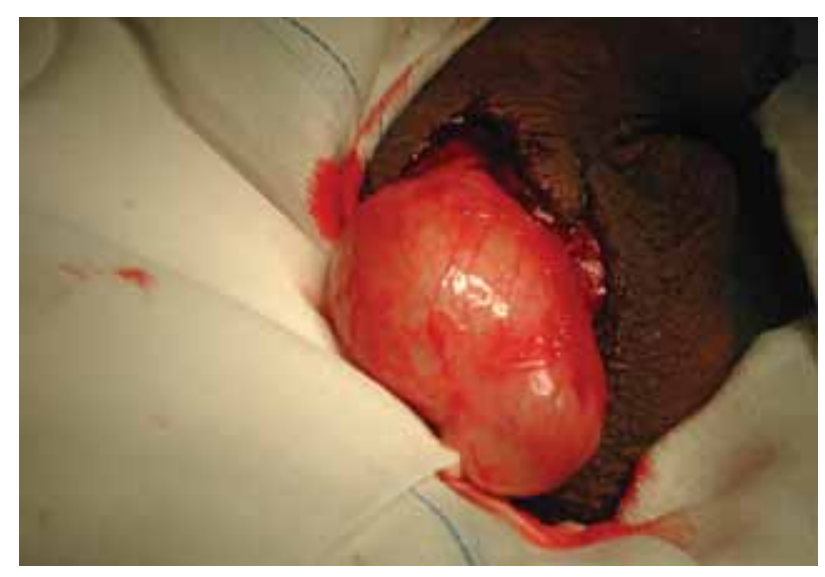

FIGURA 1.

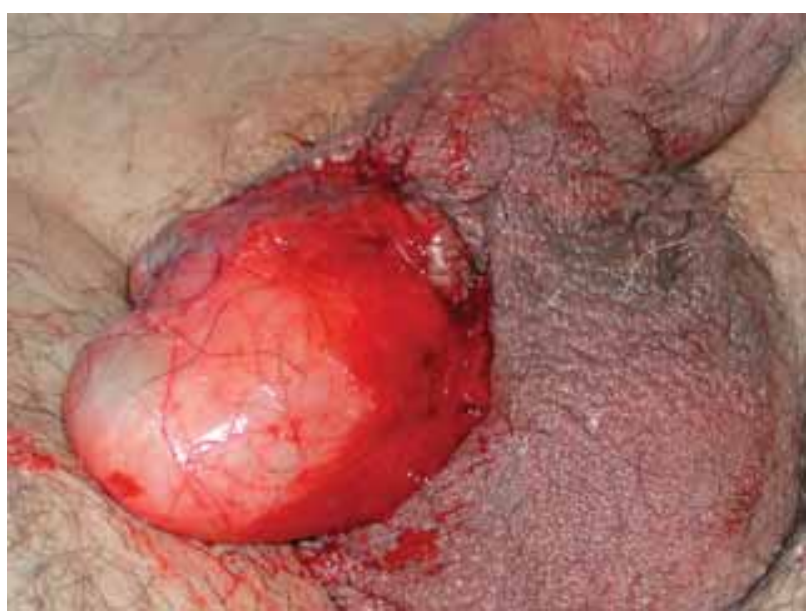

FIGURA 2.

Correspondencia autor: Dr. F. J. Lorente Pérez Servicio de Urología Clínica San Miguel.

Beloso Alto 32 - 31006 Pamplona (Navarra) Tel.: 948296000

E-mail: lorente@imqnavarra.com Información artículo: Imágenes en Urología Trabajo recibido: diciembre 2006 Trabajo aceptado: febrero 2007 